\title{
BOUNDARY PHASE STRUCTURE BETWEEN POLY(HYDROXYPROPYL ETHER OF BISPHENOL A)/POLY(METHYL METHACRYLATE) BLEND AND POLYAMIDE SUBSTRATE
}

\author{
By Minekazu Kodama and Kazuo Kuramoto \\ (Materials \& Electronic Devices Laboratory, \\ Mitsubishi Electric Corporation, \\ 1-1, Tsukaguchi-Honmachi 8-chome, Amagasaki, 661, Japan)
}

\begin{abstract}
Study of X-ray photoelectron spectroscopy (XPS) has been made on the film of poly(hydroxypropyl ether of bisphenol A) (P)/Poly (methyl methacrylate) (M) blend formed on nylon-6 substrate to elucidate the boundary phase structure between the substrate and the polymer blend. It can be found by analysing the $C_{1 s}$ spectrum that the boundary phase is almost composed of $M$ alone. This result can be useful for fundamental information to understand the reinforcing mechanism of the $\mathrm{Kevlar}^{\circledR}$-fiber reinforced composite made with $\mathrm{P} / \mathrm{M}$ blend as matrix.
\end{abstract}

\section{INTRODUCTION}

It was reported in the previous paper that the fiber efficiency factor for strength $K_{\alpha}$ increased with the fraction of polar components in the matrices for the Kevlar ${ }^{\circledR}$-fiber reinforced composites made with the blends of poly(methyl methacrylate) (M)/polystyrene (S) and poly(hydroxypropyl ether of bisphenol A) $(P) / S^{1)}$. This means that the interaction between the reinforcement and matrix increases with the fraction of polar components in the matrix.

On the contrary, $K_{a}$ of the Kevlar-fiber reinforced composite made with the blend of polar components $(\mathrm{P} / \mathrm{M})$ was larger than that anticipated from the additivity of the strength of the polar components ${ }^{1)}$. That is, a synergistic effect appears in the matrix-reinforcement interaction for the composite.

The boundary phase structure can be formed in the vicinity of reinforcement as a consequence of reinforcement-matrix interaction. In this work, the film of $\mathrm{P} / \mathrm{M}$ blend formed on nylon- 6 substrate (N) is probed by X-ray photoelectron spectroscopy (XPS) in order to explain the reinforcing mechanism of the Kevlar-fiber reinforced composite made with $\mathrm{P} / \mathrm{M}$ blend. $\mathrm{N}$ is used as a model compound for Kevlar-fiber ${ }^{2), 3)}$. It is known from XPS study that the carboxylic group and hydroxyl group or ether linkage preferencially concentrate on the $\mathrm{N}$ surface for the films of $\mathrm{M}$ and $\mathrm{P}$ formed on $\mathrm{N}$, respectively ${ }^{2), 3)}$.

\section{EXPERIMENTAL}

The $\mathrm{N}$ plate of ca. $1 \mathrm{~mm}$ thick was obtained by compression molding of Novamide 1010 (nylon-6 produced by Mitsubishi Chemical Industries Co.). The cleaned $\mathrm{N}$ plate was repeatedly dipped in a $2 \%$ blend polymer solution of tetrahydrofuran. Thickness of the coated sample was ca. $0.5 \mathrm{~mm}$. The blend ratio of $\mathrm{P} / \mathrm{M}$ was selected as $1 / 1$ by weight, as the synergistic effect mentioned above appeared significantly in the vicinity of this blend ratio ${ }^{1)}$. After removing the solvent, the polymer film formed on the $\mathrm{N}$ substrate was carefully separated from the substrate so as not to damage the film surface. By leaving the coated specimen for a week in air, the film was easily separated from the substrate. XPS spectra were measured for the separated film on the surface exposed to air (air-facing side) and $\mathrm{N}$ substrate ( $\mathrm{N}$-facing side). XPS spectra were obtained with a VG HB $50 \mathrm{~A}$ 
scanning electron microscope. An aluminum anode $X$-ray source producing $A / K_{\alpha} X$-ray at $1486.6 \mathrm{eV}$ was used by operating at $12 \mathrm{KV}$ and $20 \mathrm{~mA}$. The instrument was maintained at $1 \times 10^{-8} \mathrm{mbar}$ or less for all measurements. The data were analyzed on the high resolution spectra of the $C_{1 s}$ region. The overlapping peaks in the $C_{1 s}$ spectra were resolved into their individual components after background subtraction, assuming a Gaussian type symmetric function ${ }^{2)}$. Charge correction in the binding energy scale was made by setting the peak for hydrocarbon component at $285.0 \mathrm{eV}$ in binding energy. Angular dependence of XPS was measured by tilting the surface of the sample. The effective sampling depth would decrease with decreasing take-off angle of photoelectron $(\theta)$, which is the angle between the surface of the sample and electron analyser axis.

\section{RESULTS AND DISCUSSION}

In Figure 1, the observed $\mathrm{C}_{1 \mathrm{~s}}$ spectra (dotted curve) and resolved components (broken curves) are shown for both the air-facing and the $\mathrm{N}$-facing sides at various take-off angles. The resolved components $C_{1}, C_{2}$ and $C_{3}$ can be assigned to $\mathrm{CHx}, \mathrm{C}-\mathrm{O}$ and $\mathrm{O}-\mathrm{C}=\mathrm{O}$, respectively.

The component $C_{3}$ cannor be observed for $P$, and the relative peak area of component $C_{2}$ is nearly equal to that of $C_{3}$ in the spectrum at the largest sampling depth for the air-facing side of atactic poly(methyl methacrylate) (M) as reported in the previous works ${ }^{2), 4), 5}$ ) (the materials and experimental condition were the same as those in this work). From these facts it can be said that the component $C_{3}$ comes from $M$ alone. Therefore, $C_{3}$ can be used as a measure of the behavior of $M$ in the blend.

The boundary phase structure was probed by comparing the XPS spectra between the $\mathrm{N}$-facing and air-facing sides.

The relative peak areas of $C_{1}, C_{2}$ and $C_{3}$ components were obtained and plotted against the take-off angle $(\sin \theta)$ in Figure 2. The relative peak area of $C_{1}$ is somewhat larger than the value anticipated from the chemical structure and composition $(66.1 \%)$, and increases with decreasing $\sin \theta$ (decreasing sampling depth), in both the air-facing and $\mathrm{N}$-facing sides. This is probably due to the increase in relative peak area of $C_{1}$
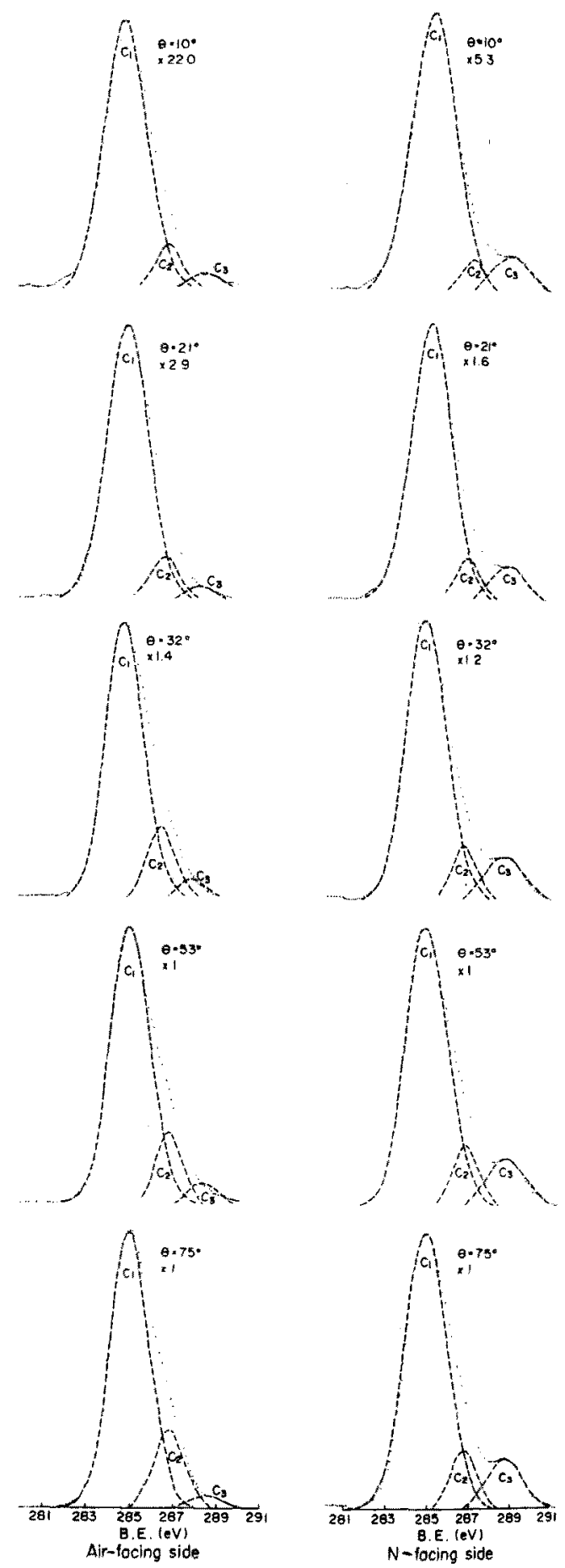

Fig. 1. XPS spectra for poly (hydroxypropyl ether of bisphenol A)/poly(methyl methacrylate) blend polymers. 

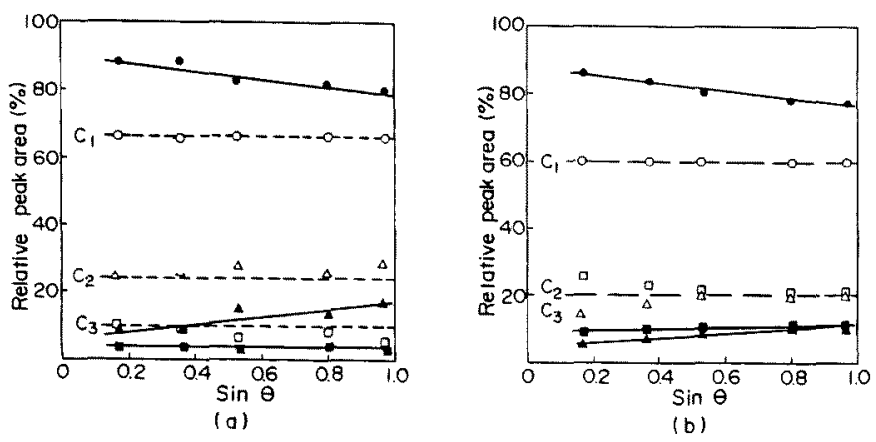

Fig. 2. Relative peak area vs. electron take-off angle relations for observed values $\left(C_{1}\right.$ : $\left.\mathrm{C}_{2}: \boldsymbol{\Lambda}, \mathrm{C}_{3}: \boldsymbol{\square}\right)$, re-estimated values $\left(\mathrm{C}_{1}: \mathrm{O}\right.$, $\left.\mathrm{C}_{2}: \triangle, \mathrm{C}_{3}: \square\right)$, anticipated values from chemical structure and composition for $\mathrm{P} / \mathrm{M}$ blend (------) and anticipated values from chemical structure for $\mathrm{M}$ (- - ) , for airfacing side (a) and $\mathrm{N}$-facing side (b).

component on account of the hydrocarbon contamination layer deposited on the sample during measurement ${ }^{6)}$.

By assuming simply the relative peak area of $\mathrm{C}_{1}$, which is free from the hydrocarbon contamination, to be $66.1 \%$ in the range of $\sin \theta$ measured at the air-facing side, the relative peak areas of $\mathrm{C}_{2}$ and $C_{3}$ were re-estimated from the observed values. The results are also shown in Figure 2. The reestimated values of $C_{2}$ and $C_{3}$ become close to those anticipated from the chemical structure and composition. At the $\mathrm{N}$-facing side, the relative peak areas of $C_{2}$ and $C_{3}$ were re-estimated from the observed values by assuming the relative peak area of $\mathrm{C}_{1}$ to be $60 \%$, which is free from the hydrocarbon contamination. The re-estimated values of $C_{2}$ and $C_{3}$ become close to the relative peak areas of $C_{2}$ and $C_{3}$ for $M$ homopolymer anticipated from the chemical structure. This means that the boundary phase is composed of almost $\mathrm{M}$ alone.

The carbonyl-containing polymer poly(ethylene adipate) (A) also concentrates at the $\mathrm{N}$-facing side for the case of $\mathrm{P} / \mathrm{A}$ blend film formed on $\mathrm{N}$ as reported in the previous paper ${ }^{2)}, \mathrm{N}$ and $\mathrm{P}$ are known to self-associate through strong hydrogen bonding ${ }^{7), 8)}$. Therefore, $M$ or $A$, which is not hydrogen bonded by itself, tends to concentrate on the self-associated substrate when the blend of hydrogen bonded polymer with $\mathrm{M}$ or $\mathrm{A}(\mathrm{P} / \mathrm{M}$ or $\mathrm{P} / \mathrm{A}$ ) contacts with the substrate. This is probably because of the easier occurrence of interaction between $\mathrm{N}$ and $\mathrm{M}$ or $\mathrm{A}$ compared with the case of $N$ and $P$. The carbonyl-containing polymers, $M$ and. $A$, can also destroy the selfassociation of $\mathrm{P}$ and interact with the dessociated $\mathrm{P}^{2), 8)}$. If, such a boundary phase structure is formed in the Kevlar-fiber reinforced composite made with $\mathrm{P} / \mathrm{M}$ blend, the synergistic effect as mentioned above may arise in the composite.

\section{References}

1) M. Kodama and I. Karino, J. Appl. Polym. Sci., 32, 5057 (1986).

2) M. Kodama, K. Kuramoto and I. Karino, $J$. Appl. Polym. Sci., 34, 1889 (1987).

3) M. Kodama and K. Kuramoto, Polymer J., 20, 515 (1988).

4) M. Kodama, I. Karino and K. Kuramoto, Polym.-Plast. Technol. Eng.. 27 (1), 127 (1988).

5) M. Kodama and K. Kuramoto, Sen-i Gakkaishi, 44, No 11, 1 (1988).

6) D. H. K. Pan and W. M. Prest, Jr., J. Appl. Phys., 58, 2861 (1985).

7) G.M. Venkatesh, R.D. Gilbert and R.F. Fornes, Polymer, 26, 45 (1985); D.J. Skrovanek, S.E. Howe, P.C. Painter and M.M. Coleman, Macromolecules, 18, 1676 (1985).

8) M. M. Coleman and E. J. Moskala, Polymer, 24, 251 (1983). 
フェノキシ樹脂/ポリメタクリル酸メチル

ブレンドとポリアミド基材間境界相の構造

三菱電機(株)材料研究所 归玉峯一，倉本一雄

ナイロン -6 基材上に形成したフェ/キシ樹脂 (P)/ ポリメタクリル酸メチル $(\mathrm{M})$ ブレンド物のフィルムにつ いて，基材とブレンド高分子間境界相の構造を調べるた めに，X線光電子分光スペクトルを測定した。 $C_{1 \mathrm{~s}}$ スペ
クトルの解析結果から，境界相はほとんどMだけで構成 されていることがわかった。これは， $P / M$ ブレンド物 をマトリックスとするケブラー䄉維強化複合体の強化機 構党理解する上での基本的な知見となる。 